Euskal ikerketen aldizkaria | Revue d'études basques |

Revista de estudios vascos | Basque studies review

Numéro spécial 4 | 2019

SACAZE bildumako euskal testuak (1887)

\title{
Jatorrizko frantses testua
}

\section{Gotzon Aurrekoetxea, Charles Videgain et Aitor Iglesias Chaves}

\section{OpenEdition \\ Journals}

Édition électronique

URL : https://journals.openedition.org/lapurdum/2886

DOI : 10.4000/lapurdum.2886

ISSN : 1965-0655

Éditeur

IKER

Édition imprimée

Date de publication : 1 octobre 2019

Pagination : 31

ISBN : 9782955341339

ISSN : $1273-3830$

\section{Référence électronique}

Gotzon Aurrekoetxea, Charles Videgain eta Aitor Iglesias Chaves, «Jatorrizko frantses testua», Lapurdum [Linean], Numéro spécial 4 | 2019, Sarean emana----an 12 janvier 2020, kontsultatu 22 septembre 2022. URL: http://journals.openedition.org/lapurdum/2886 ; DOI: https://doi.org/10.4000/ lapurdum.2886

\section{(c) (i) (2)}

Creative Commons - Attribution-NonCommercial-NoDerivatives 4.0 International - CC BY-NC-ND 4.0 https://creativecommons.org/licenses/by-nc-nd/4.0/ 


\section{JATORRIZKO FRANTSES TESTUA}

\section{I - La légende de Barbazan}

Il y avait autrefois dans un village des Pyrénées un homme et une femme qui étaient très vieux. Ils n'avaient qu'une petite maison, un jardin et une vache. Mais, si pauvres qu'ils fussent, ils secouraient toujours ceux qui étaient plus pauvres qu'eux. Un jour, la terre était couverte de neige, et il gelait à pierre fendre. Tous les gens du village se chauffaient, en mangeant et buvant ; ils étaient riches et heureux. A l'entrée de la nuit, deux voyageurs qui venaient de loin voulurent s'arrêter dans ce lieu, parce qu'ils avaient froid et faim; ils frappèrent à une porte, puis à une autre et à d'autres encore ; personne ne voulut les laisser entrer, ni leur rien donner à manger. Chassés de partout, poursuivis par des chiens furieux, les deux étrangers ne savaient où aller, quand ils se trouvèrent à l'extrémité du village, devant la maison de cet homme et cette femme qui étaient si pauvres. En entendant leur plainte, le mari s'était mis à la fenêtre pour les appeler, et sa femme était allée vite ouvrir la porte. Sans leur demander qui ils étaient, ils les firent entrer et asseoir à leur foyer ; puis, ils ${ }^{2}$ leur servirent du lait et quelques châtaignes, tout ce qu'ils avaient, mais alors, Notre-Seigneur, -c'était lui, avec Saint Pierre,- se leva, la tête toute brillante, et il leur dit : «Vous autres, vous êtes pauvres et bons; vos voisins sont riches et méchants. Que la justice de Dieu se fasse ! » Aussitôt la terre trembla, Jésus et Saint Pierre disparurent et les deux vieillards tombèrent à genoux... Le lendemain matin, quand ils voulurent aller au village, pour savoir ce qui s'était passé, ils ne virent aucune maison : à leur place, il y avait un lac, celui qui se trouve encore aujourd'hui entre le village de Barbazan et la ville de Saint-Bertrand de Comminges. Il faut assister les malheureux.

\section{II - La légende de Tantugou}

Tantugou est un vieillard qui se cache dans les bois. Il garde les champs et les prés pour qu'on n'y vole rien. Quand les blés sont coupés ou l'herbe fauchée, jusqu'à ce que tout soit retiré par le maître, Tantugou ne dort point ; il veille toujours. La peur de le voir paraître retient les voleurs. Il est bon, croyez-le, mais il est sauvage. Un laboureur qui savait bien des choses disait souvent à ses fils que Tantugou était sûrement le meilleur gardien des fruits de la terre.

Un après-midi du mois de juillet, un troupeau de brebis paissait sur une montagne; le berger s'endormit : en se réveillant, il aperçut Tantugou qui s'enfuyait vers le bois. Il fut également reconnu par les pâtres dans une jolie vallée, couché sur un rocher.

Encore aujourd'hui, dans quelques villages des Pyrénées, les enfants ont peur de lui. Quand un petit garçon ou une petite fille ne veut pas obéir à sa mère, elle lui dit : Prends garde à toi ! j'appelle Tantugou et, à l'instant, il va venir du bois !

2. Testuak « il » ekartzen du. Baina huts tipografikoa dela kontsideratzen dugu, plurala behar duelakotz eta « ils» ezarri dugu. Etxeko bi zaharrak dira « ils » horiek. 